\title{
„Dum spiro spero": a SARS-CoV-2-fertőzés klinikopatológiája 26 eset kapcsán
}

\author{
Zombori Tamás dr. ${ }^{1}$ - Kuthi Levente dr. ${ }^{1}$ - Hortobágyi Tibor dr. ${ }^{1}$ \\ Csörgő Erika dr. ${ }^{2}$ - Árgyelán János $\mathrm{dr}^{2}{ }^{2}$ - Kocsis Lajos dr. ${ }^{2}$ \\ Sejben István dr. ${ }^{2}$ - Kaizer László dr. ${ }^{1}$ - Radics Bence dr. ${ }^{1}$. Sejben Anita dr. ${ }^{1}$ \\ Pancsa Tamás dr. ${ }^{1}$ - Nyári Gergely Róbert dr. ${ }^{1}$ - Baráth Bence dr. ${ }^{1}$ \\ Cserni Gábor dr. ${ }^{1,2}$ - Iványi Béla dr. ${ }^{1}$ - Tiszlavicz László dr. ${ }^{1}$
}

${ }^{1}$ Szegedi Tudományegyetem, Általános Orvostudományi Kar, Patológiai Intézet, Szeged ${ }^{2}$ Bács-Kiskun Megyei Oktatókórház, Kecskemét

Bevezetés: A kórboncolás hozzájárul a súlyos akut légzőszervi szindrómát okozó koronavírus-2 (SARS-CoV-2-) fertôzés klinikopatológiai vonatkozásainak megismeréséhez.

Célkitüzés: A SARS-CoV-2-fertőzöttek boncolása során gyưjtött tapasztalatok bemutatása.

Módszer: Egymást követően boncolt, védőoltásban nem részesült, SARS-CoV-2-fertôzött elhunytak klinikai adatait, makro- és mikroszkópos észleleteit összegeztük; a tüdőkimetszéseket SARS-CoV-2-nukleokapszid-immunfestéssel vizsgáltuk.

Eredmények: A boncolást a halálok megállapítására $(\mathrm{n}=14)$, tumorgyanú $(\mathrm{n}=9)$, illetve törvényi kötelezettség $(\mathrm{n}=3)$ miatt végeztük. A fertőzést a klinikai észlelés vagy a boncolás során $(\mathrm{n}=4)$ végzett SARS-CoV-2-nukleinsavteszt igazolta. A tünetes betegség átlagos hossza 12,9 nap volt. 21 betegnél (medián életkor 69 év; 18 férfi) állt fenn COVID-19-pneumonia, mely 16 esetben önmagában, 4 esetben bakteriális pneumoniával vagy álhártyás colitisszel szövődve okozott halált; 1 antikoagulált pneumoniás beteg heveny retroperitonealis vérzésben halt meg. 3 betegnél a halált disszeminálódott malignus tumor, l betegnél coronariathrombosis, 1 mentálisan retardált betegnél pedig pulmonalis emboliás szövődmény okozta. A COVID-19-pneumoniás tüdők nehezek, tömöttek és vörösen foltozottak voltak. Szövettanilag a betegség időtartamától függően diffúz alveolaris károsodás korai exsudativ vagy későbbi proliferativ fázisa látszott atípusos pneumocytákkal; gyakori volt a microthrombosis $(\mathrm{n}=7)$, a macrothrombosis $(\mathrm{n}=5)$, illetve a pulmonalis embolia $(\mathrm{n}=4)$. A SARS-CoV-2-immunfestés pozitívnak bizonyult az esetek 38,5\%ában, dominálóan az exsudativ fázisban. Minden elhunyt társbetegség(ek)ben szenvedett, így magasvérnyomás-betegségben $(n=17)$, érelmeszesedésben $(n=14)$, 2-es típusú diabetesben $(n=8)$, rosszindulatú daganatban $(n=6)$, krónikus obstruktív tüdőbetegségben $(\mathrm{n}=4)$, elhízásban $(\mathrm{n}=3)$, vesetranszplantáció utáni immunszuppresszióban $(\mathrm{n}=3)$.

Következtetés: Az irodalmi adatokkal összhangban, halálos COVID-19-pneumonia túlnyomóan idős, társbetegség(ek)től sújtott férfiakban alakult ki. A boncolási gyakorlatban a SARS-CoV-2-nukleokapszid-immunfestéstől a diffúz alveolaris károsodás korai fázisában várható pozitivitás.

Orv Hetil. 2021; 162(45): 1791-1802.

Kulcsszavak: SARS-CoV-2-fertőzés, klinikopatológia, COVID-19-tüdőgyulladás, immunhisztokémia

\section{"Dum spiro spero": clinicopathologic characteristics of SARS-CoV-2 infection}

Introduction: Autopsy is an important tool for the evaluation of severe acute respiratory syndrome coronavirus-2 (SARS-CoV-2) infection.

Objectice: The aim of this study was to present our experience with autopsies of patients diagnosed with SARS-CoV-2 infection.

Method: Clinical data, macroscopic and microscopic findings of consecutive postmortems of non-vaccinated SARSCoV-2 patients are summarized. Lung samples were evaluated with SARS-CoV-2 nucleocapsid immunohistochemistry. 
Results: Autopsies were performed to determine the cause of death $(\mathrm{n}=14)$, suspected tumours $(\mathrm{n}=9)$ or due to legal obligation $(\mathrm{n}=3)$. SARS-CoV-2 infection was verified by ante mortem $(\mathrm{n}=22)$ and post mortem $(\mathrm{n}=4)$ polymerase chain reaction. The mean duration of symptomatic disease was 12.9 days. Of 21 patients with COVID-19 pneumonia, 16 died of respiratory failure, 4 had additional bacterial pneumonia or Clostridioides difficile infection, and 1 developed hemorrhagic complication $(n=1)$. Other causes of death included disseminated malignancies $(\mathrm{n}=3)$, coronary thrombosis $(\mathrm{n}=1)$ and pulmonary embolism $(\mathrm{n}=1)$. The affected lungs were heavy and had patchy red appearance. Exudative or proliferative phases of diffuse alveolar damage (DAD) were detected with atypical pneumocytes. Microthrombosis $(n=7)$, macrothrombosis $(n=5)$ and pulmonary embolism $(n=4)$ were frequent. The SARS-CoV-2 immunohistochemical reaction was positive in $38.5 \%$ of cases. All patients had co-morbidities, namely, hypertension $(n=17)$, atherosclerosis $(n=14)$, diabetes $(n=8)$, malignancies $(n=6)$, chronic obstructive pulmonary diseases $(n=4)$, obesity $(n=3)$ and immunosuppression after kidney transplantation $(n=3)$.

Conclusion: Fatal COVID-19 pneumonia occurred mostly in elderly males with co-morbidities. In the autopsy practice, the SARS-CoV-2 nucleocapsid immunohistochemical reaction may confirm the infectious etiology in the early phase of DAD.

Keywords: SARS-CoV-2 infection, clinicopathological findings, COVID-19 pneumonia, immunohistochemistry

Zombori T, Kuthi L, Hortobágyi T, Csörgő E, Árgyelán J, Kocsis L, Sejben I, Kaizer L, Radics B, Sejben A, Pancsa T, Nyári GR, Baráth B, Cserni G, Iványi B, Tiszlavicz L. [ "Dum spiro spero": clinicopathologic characteristics of SARS-CoV-2 infection]. Orv Hetil. 2021; 162(45): 1791-1802.

(Beérkezett: 2021. augusztus 19.; elfogadva: 2021. szeptember 19.)

\section{Rövidítések}

ARDS $=($ acute respiratory distress syndrome $)$ akut légzőszervi distressz szindróma; $\mathrm{CDC}=($ Centers of Disease Control and Prevention) Járványügyi és Betegségmegelőzési Központ (USA); CI $=$ (confidence interval) konfidenciaintervallum; COVID-19 = (coronavirus disease 2019) koronavírus-betegség 2019; CT = (computed tomography) komputertomográfia; $\mathrm{DAD}=$ (diffuse alveolar damage) diffúz alveolaris károsodás; $\mathrm{eDAD}=$ exsudativ fázisú diffúz alveolaris károsodás IFN-I $=$ interferon-I; PCR $=($ polymerase chain reaction $)$ polimeráz-láncreakció; $\mathrm{pDAD}$ = proliferatív fázisú diffúz alveolaris károsodás; RNS = ribonukleinsav; SARS $=($ severe acute respiratory syndrome) súlyos akut légúti tünetegyüttes; SARS$\mathrm{CoV}-2=($ severe acute respiratory syndrome coronavirus 2$)$ súlyos akut légúti tünetegyüttest okozó koronavírus-2; SZTE = Szegedi Tudományegyetem

A koronavírusok a Coronaviridae család Orthocoronavirinae alcsaládjába tartozó RNS-vírusok, és általában enyhe légúti tünetekkel járó megbetegedést váltanak ki [1]. Sajnos a 2019-ben a kínai Vuhan városából kiindult és világjárvánnyá vált, súlyos akut légzőszervi szindrómát okozó koronavírus-2 (SARS-CoV-2-) fertózés komoly szövődményeket idéz elő a fertőzöttek egy részében [2]. A kórképet koronavírus-betegség 2019-nek (COVID-19) nevezték el. A vírus tüskefehérjéi a légutak hámsejtjein, a pneumocytákon és az alveolaris macrophagokon kifejeződő angiotenzinkonvertáló enzim-2 receptorához kötődnek, majd a vírus bejut a gazdasejtekbe. A vírus olyan fehérjéket kódol, amelyekkel elkerüli/ellensúlyozza a szervezet antivirális hatású és az immunrendszer egyes funkcióit szabályozó interferon-I (IFN-I) válaszreakcióját, ráadásul a fertőzöttek egy részénél az IFN-stimulált géneket aktiváló jelutak genetikai/szer- zett defektusa és/vagy T-sejtes lymphopenia áll fenn ( 65 év felett a naiv T-lymphocyták száma csökkent lehet), ily módon a SARS-CoV-2-fertőzésre adott immunválasz hatásossága elmaradhat a kívánatostól. Az IFN-I-válaszkészség alapján három klinikai fenotípus különíthetô el [3]. Az erőteljes IFN-I-válasz gyors víruseliminációt eredményez, a fertőzöttek jobbára fiatalok és csupán tünetmentes hordozók. Mérsékelt IFN-I-válasz esetén elhúzódik a víruselimináció, enyhe vagy közepesen súlyos víruspneumoniával járó, tünetes betegség alakul ki. Gyenge IFN-I-válaszkor ineffektív a víruselimináció, és súlyos víruspneumonia jön létre, ráadásul túlaktiválódhatnak a veleszületett immunválasz ösvényei, és kritikussá válhat az általános állapot: gépi lélegeztetést igénylő tüdőgyulladás/akut légzőszervi distressz szindróma (ARDS), sokk/szeptikus sokk, többszervi diszfunkció jelentkezik [4]. Gyenge IFN-I-válasz többnyire az idősebbekben tapasztalható. A COVID-19 halálozási rátáját jelentősen befolyásolja a cseppfertózés intenzitása, az életkor, a férfinem, illetve az önmagukban potenciálisan halálos betegségek/állapotok fönnállása, mint például a krónikus cardiovascularis betegség, az idült obstruktív légúti betegség, az asztma, az elhízás, a diabetes, az idült veseelégtelenség, az immunszupprimált állapot, illetve az aktív rosszindulatú daganat.

A pandémia kezdetén a COVID-19-fertőzöttek kórboncolása számos országban, így hazánkban is felfüggesztésre került [5-8]. A kórboncolások során alkalmazandó biztonsági intézkedések nemzetközi [9-11] és hazai kidolgozása [12] lehetôvé tette a kórboncolások biztonságos kivitelezését, majd úiraengedélyezését. A COVID-19-fertőzésben meghaltak haláloki elemzése orvosi szempontból nem könnyű feladat. Magyarországon miniszteri utasítás alapján a halál okát megállapító 
orvos két lehetőség közül választ. 1) Ha az elhunyt kórtörténetében olyan krónikus betegség vagy állapot szerepel, amely önmagában is halálhoz vezetett volna, akkor a halottvizsgálati bizonyítványban az alapbetegség rovatába az ismert krónikus betegséget, a közvetlen halálok rovatába pedig a krónikus betegség akut szövődményét tünteti fel, a COVID-19-fertőzés tényét pedig a kísérő betegségek rovatában szerepelteti. 2) Ha az elhunyt kórtörténetében nem szerepel olyan betegség vagy állapot, amely a halálozást magyarázhatja, úgy a COVID-19-fertőzés tényét alapbetegségként tünteti fel [13].

Célunk két hazai patológiai osztályon a SARS-CoV2-fertőzéssel kórismézett és elhunyt betegek kórboncolása során észlelt makroszkópos, mikroszkópos, illetve immunhisztokémiai eltérések és klinikopatológiai összefüggések bemutatása.

\section{Anyag és módszerek}

Retrospektív, konszekutív vizsgálatunkba a 2020. 09. 01. és 2021. 05. 10. között a Szegedi Tudományegyetem (SZTE) Patológiai Intézetében, illetve a kecskeméti Bács-Kiskun Megyei Oktatókórházban boncolásra került, SARS-CoV-2-fertőzéssel kórismézett betegeket válogattuk be. A vírusinfekció igazolása polimeráz-láncreakción (PCR) alapuló, ante mortem vagy post mortem tesztelésen alapult. 2 beteg esetében a halál előtti PCRvizsgálat már negatív eredménnyel zárult, ugyanakkor a halál ok-okozati összefüggésben állt a vírusfertőzéssel, így ezeket az eseteket sem zártuk ki. Eseteinknél teljes szervi boncolást vagy limitált boncolást végeztünk. Az előbbinél valamennyi zsigeri szerv makroszkópos észlelésre került, míg az utóbbi esetben a vizsgálat csak a mellkasi szervekre korlátozódott. A teljes szervi boncolás során szövettani elemzésre szánt szervek a következók voltak: a tüdő, a szív, a máj, a lép, a vese, valamint az esetek egy részében a hasnyálmirigy, az agy, a csontvelő és a mellékvese is vizsgálatra került.

A tüdőből a makroszkóposan észlelt kóros-ép határ területéről történtek kimetszések; 5 esetben a Calabrese és mtsai által ajánlott szisztematikus tüdőfeldolgozásra is sor került [14]. A kimetszéseket 10\%-os formalinban minimum 24 órán át rögzítettük, paraffinba ágyaztuk, majd $4 \mu \mathrm{m}$ vastagságú metszeteket készítettünk. A hematoxilin-eozin festett metszeteket két patológus (Z. T., I. B.) újravizsgálta, majd értékelte a pulmonalis és extrapulmonalis szövettani jellegzetességeket. Best Rocha és mtsai közleményét alapul véve, valamennyi elhunyt tüdőkimetszésén immunhisztokémiai reakciót végeztünk a hazánkban akkor egyedül elérhető, egérben termelt, monoklonális anti-SARS-CoV-2-nukleokapszid- (B46F, Invitrogen, Waltham, MA, USA) antitesttel, 1 : 100 hígításon [15]. A kiértékelés során negatív kontroll mellett vizsgáltuk a festődés intenzitását és lokalizációját. Pozitívnak definiáltuk az esetet, ha legalább 2-3+ intenzitású reakció látszott a hialinmembránokban és/vagy a macrophagokban és/vagy a pneumocytákban.
A klinikai adatokat a kórházi zárójelentésből, illetve a boncolási értesítőből nyertük. Vizsgáltuk a betegek életkorát, a vezető klinikai tüneteket, a laboreltéréseket, a képalkotó eljárásokkal nyert eredményeket, a CT-vizsgálattal felállított COVID-19-pneumonia gradusát, a betegség időtartamát, a lélegeztetés módját, illetve a lélegeztetés időtartamát. Vizsgáltuk a halottvizsgálati bizonyítványokon szereplő alapbetegségeket és halálokokat, illetve a szövődményeket. A társbetegségeket a halottvizsgálati bizonyítvány, a kórházi zárójelentés és a kórboncolási epikrízis alapján összesítettük. Vizsgálatunkat az SZTE Szent-Györgyi Albert Klinikai Központjának Humán Orvosbiológiai Regionális és Intézményi Kutatásetikai Bizottsága engedélyezte (49/B92/2021).

\section{Eredmények}

A vizsgált időintervallumból 26 elhunyt (20 férfi, 6 nő) adatait elemeztük, a klinikai adatok szerint egyikük sem kapott védőoltást. A SARS-CoV-2-fertőzés 22 betegnél ante mortem, illetve 4 betegnél post mortem PCR-vizsgálattal igazolódott. A kórboncolások közül 21 az SZTE Patológiai Intézetében, 5 pedig a Bács-Kiskun Megyei Oktatókórház Patológiai Osztályán történt. Az elhunytak 85\%-a kórházban halt meg $(\mathrm{n}=22)$; az elemzésbe 4 , otthonában meghalt beteg is bekerült. Az utóbbiaknál történt a post mortem PCR-verifikáció, a halál és a mintavétel között átlagosan 4 nap (2-7 nap) telt el. A betegek átlagéletkora 65,1 év volt (medián 69,3 év; tartomány 2-90 év). A kórházba kerüléskor a vezető tünetek a nehézlégzés ( $\mathrm{n}=9)$, a láz $(\mathrm{n}=7)$, a gyengeség $(\mathrm{n}=5)$ és a száraz köhögés $(\mathrm{n}=3)$ voltak. A további tünetek között a hányinger, a hányás, a hasmenés, a vérköpés, a deréktáji fájdalom, az étvágytalanság, az aluszékonyság és az izomfájdalom érdemel említést. A laboreltéréseket illetően a leggyakrabban $(n=12)$ a C-reaktív protein szintjének emelkedése volt megfigyelhető, melyet a D-dimer- $(\mathrm{n}=7)$ és a prokalcitoninszint emelkedése követett $(\mathrm{n}=3)$. A fóbb klinikopatológiai jellemzőket az 1. táblázat mutatja be. 21 betegnél igazolódott fatális COVID-19-pneumonia, a medián életkor 69 év volt (tartomány: 39-90 év, férfi : nő arány: 18 : 3). 14 betegnél került sor CT-vizsgálatra, COVID-19-pneumoniát 11 esetben kórisméztek. A pneumonia súlyosságának medián 'grade'-je 4-es volt. 4 páciensnél került sor mellkas-röntgenvizsgálatra. A COVID-19 átlagos időtartama, amennyiben a tünetek megjelenésétól számítjuk az intervallum kezdetét, 12,9 nap volt (medián: 13 nap, tartomány: 0-29 nap); amennyiben az első pozitív PCRvizsgálatot tekintjük kezdőpontnak, 12,3 napnak bizonyult (medián: 7 nap, tartomány: 0-38 nap). Az esetek többségében ( $\mathrm{n}=15)$ oxigénszupplementációra, 4 betegnél intermittáló pozitív nyomású lélegeztetésre, 3 esetben pedig invazív gépi lélegeztetésre volt szükség. A 4, kórházon kívül elhunyt beteg nem részesült lélegeztetésben. A lélegeztetés átlagos időtartama 8 nap volt (medián: 4 nap, tartomány: 30 perc-27 nap). A kórbon- 


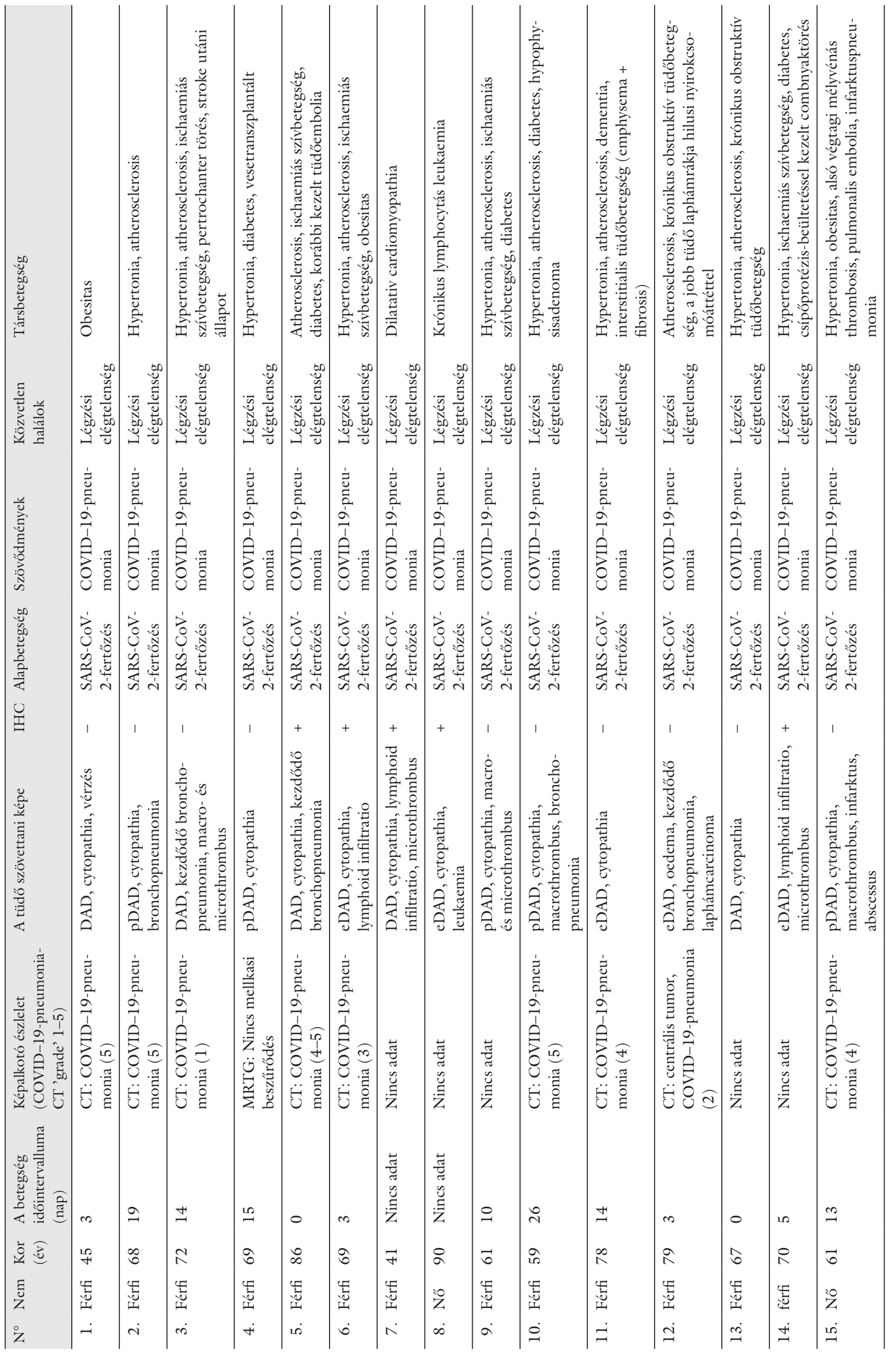




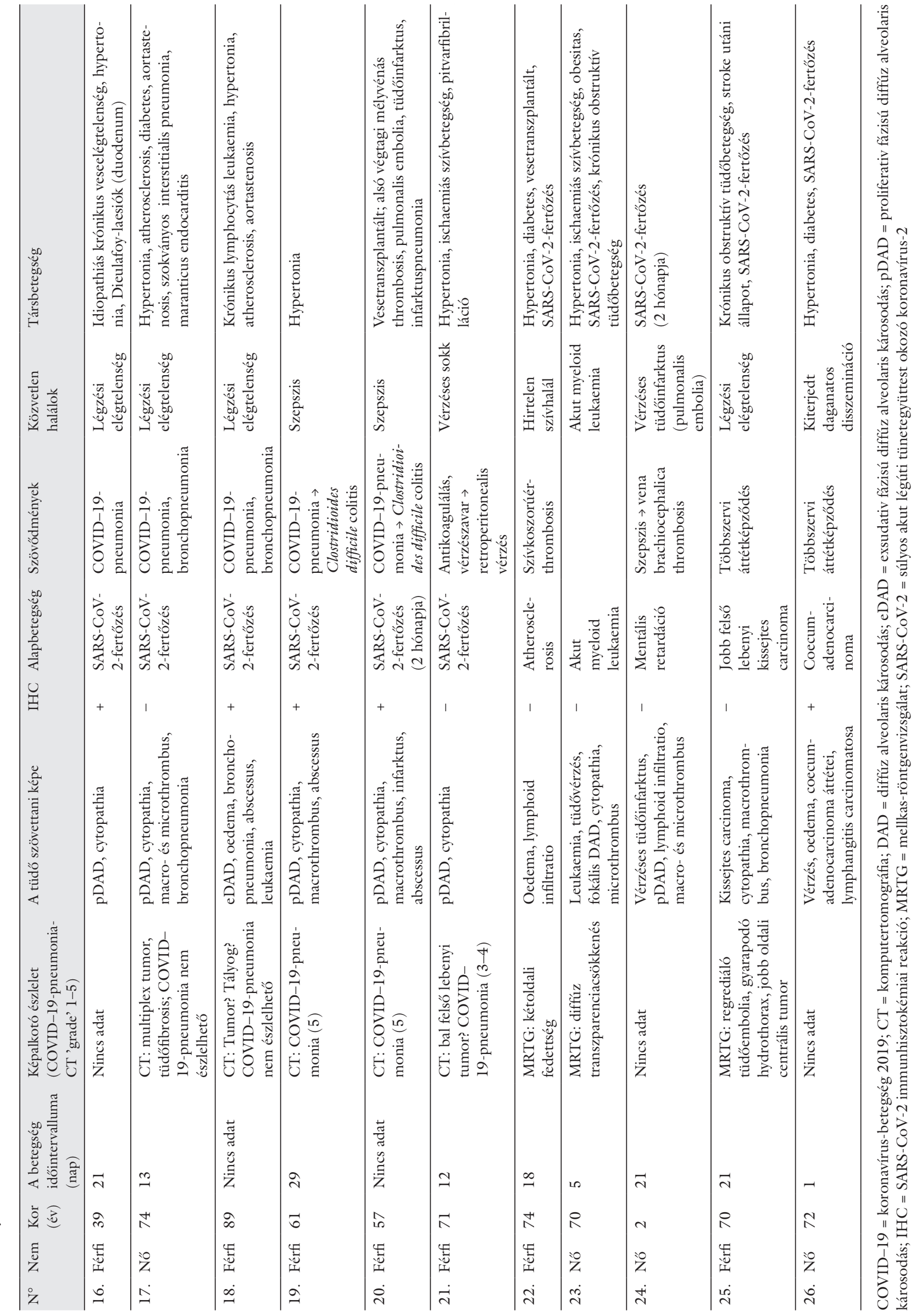


colások indikációi 9 esetben tumorgyanú, 3 esetben korábban végzett vesetranszplantáció miatti törvényi kötelezettség, 4 betegnél ismeretlen halálozási körülmény, továbbá klinikusokban felmerült kérdések $(\mathrm{n}=10)$ voltak. A leggyakoribb klinikusi kérdések a tüdők bakteriális szuperinfekciójára $(\mathrm{n}=3)$, tüdőembolia jelenlétére $(\mathrm{n}=2)$, a gyors állapotromlás lehetséges okaira $(\mathrm{n}=2)$, a COVID-19-pneumonia kiterjedtségére $(n=1)$, illetve a terápiás beavatkozások esetleges szövődményeire $(\mathrm{n}=2)$ vonatkoztak. Teljes szervi boncolás történt 19 esetben, melynek keretében a szervek makroszkópos észlelése mellett a parenchymás szervekből (szív, tüdő, máj, lép, vese) történtek kimetszések szövettani vizsgálatra. Az agy boncolására három esetben került sor. További kimetszések készültek még egyes esetekben a csontvelőból $(n=6)$ és a mellékveséből $(n=7)$ is. A tüdőkimetszések 8 betegnél szisztematikusan történtek. 5 esetben mindkét tüdő formalinfixálásra került, és a rögzülést követően a szervek metszéslapjáról képi dokumentáció készült.

A víruspneumoniára jellegzetes makroszkópos eltéréseket az 1. ábra mutatja be. A COVID-19-pneumonia
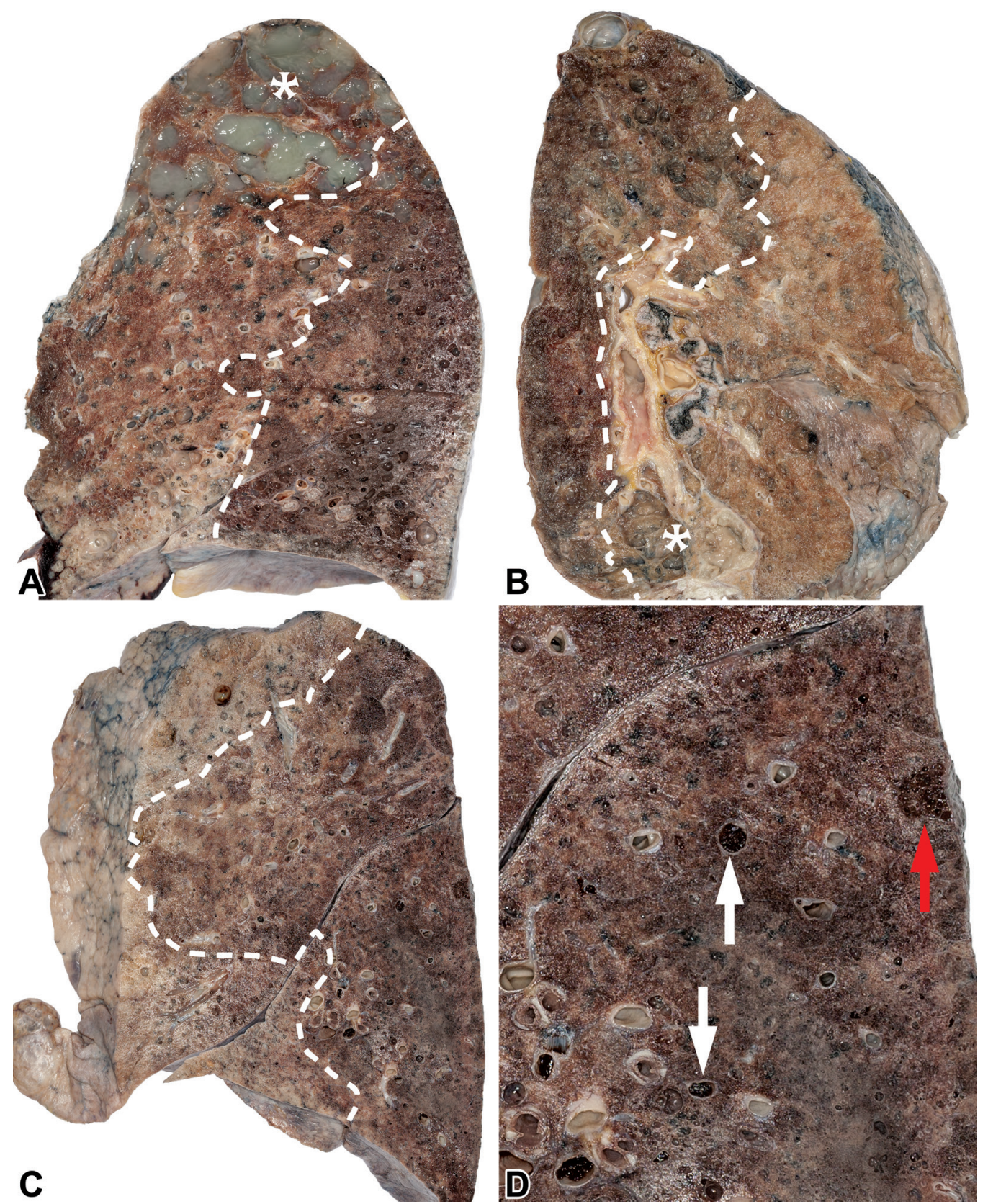

1. ábra

A SARS-CoV-2-pneumonia makroszkópos megjelenése az egész tüdő fixálását követően. A fehér szaggatott vonal az ép-kóros tüdőállomány határát jelöli. A) Paravertebralisan sötét foltozottság észlelhető az interstitialis tüdőbetegséggel kórismézett betegben (* nyákkal telt bullák). B) Krónikus lymphocytás leukaemiával kezelt betegben paravertebralisan és a felső lebenyben sötét foltozottság észlelhető, az alsó lebenyben tályoggal $(*)$. C) Csaknem az egész tüdôt érintő sötét foltozottság. D) A „C” eset felnagyított képén a pulmonalis artériákban thrombusok (fehér nyilak), illetve vérzéses tüdőinfarktus (vörös nyíl) mutatkozik.

SARS-CoV-2 = súlyos akut légúti tünetegyüttest okozó koronavírus-2 
által érintett területek a metszéslapokon általában foltosan, az ép területekkel váltakozva jelentek meg. Friss metszéslapon az érintett tüdőrész sötétvörös, a fixálást követően sötétbarna megjelenésû volt (1. ábra). További 18 esetben a radiológiai elváltozásnak megfelelően elhelyezkedő tüdőrégióból származó kimetszés került szövettani vizsgálatra, illetve 7 betegnél csak részleges boncolás történt. A COVID-19-pneumonia során a tüdőben észlelt mikroszkópos elváltozásokat a 2. táblázat- ban találhatjuk csökkenő gyakorisági sorrendben. Az esetek kétharmadában jelen volt a hialinmembrán $(2 / A$ ábra), az intraalveolaris vizenyő, a macrophagakkumuláció (2/B ábra), valamint a pneumocytákban és a macrophagokban kialakult vírus cytopathiás hatás $(2 / B$ ábra - inszert). A vizsgált betegek mintegy felében észleltünk interstitialis lymphoid infiltratiót (2/C ábra), intraalveolaris vérzést, desquamativ bronchitist, illetve pneumocytadesquamatiót. Bakteriális felülfertőződés következté-
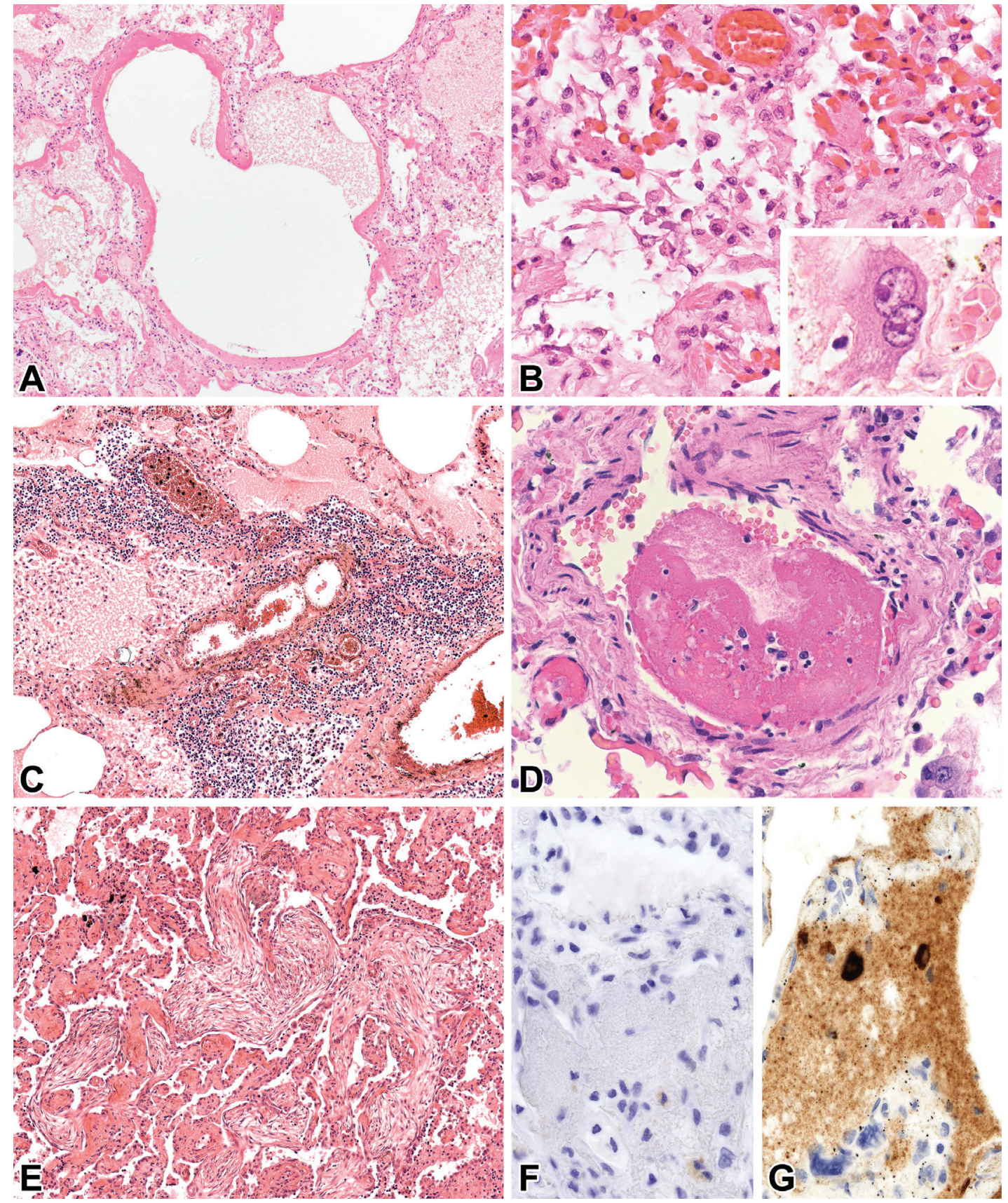

2. ábra

\footnotetext{
A SARS-CoV-2-pneumonia során a tüdőben észlelt mikroszkópos eltérések. A) Intraalveolaris hialinmembrán (HE, 10×). B) Intraalveolaris mac rophagakkumuláció $(\mathrm{HE}, 20 \times$ ). Inszert: két maggal, prominens magvacskákkal rendelkező atypusos pneumocyta; HE, 60×. C) Perivascularis interstitialis lymphoid infiltratio $(\mathrm{HE}, 20 \times)$. D) Pulmonalis arteriolában észlelt thrombus $(\mathrm{HE}, 40 \times)$. E) Proliferativ fázisú diffúz alveolaris károsodásra utaló intraalveolaris Masson-polyp-képződés (HE, 10×). F) Immunhisztokémiai reakció negatív kontrollja. G) SARS-CoV-2-nukleokapszid (B46F)expresszió a hialinmembránban, illetve macrophagokban (SARS-CoV-2-immunhisztokémia, 40×).

$\mathrm{HE}=$ hematoxilin-eozin festés; SARS-CoV-2 = súlyos akut légúti tünetegyüttest okozó koronavírus-2
} 


\begin{tabular}{lcc}
\hline & $\begin{array}{c}\text { Jelen } \\
\text { van }(\mathrm{n})\end{array}$ & \\
\hline Hialinmembrán & 23 & 88,5 \\
Macrophagok & 20 & 76,9 \\
Oedema & 20 & 76,9 \\
Vírus cytopathiás hatást mutató pneumocyták & 19 & 73,1 \\
Lymphoid infiltratio & 16 & 61,5 \\
Vérzés & 15 & 57,7 \\
Desquamativ bronchitis & 15 & 57,7 \\
Pneumocytadesquamatio & 14 & 53,8 \\
Bronchopneumonia & 11 & 42,3 \\
Macrothrombus & 9 & 34,6 \\
Megakaryocyta & 8 & 30,8 \\
Laphám-metaplasia & 6 & 23,1 \\
Organizálódó pneumonia & 6 & 23,1 \\
Microthrombusok & 6 & 23,1 \\
Tályog & 3 & 11,5 \\
Empyema & 2 & 7,7 \\
\hline
\end{tabular}

ben kialakuló bronchopneumoniát az esetek 42\%-ában figyeltünk meg. Összesen 17 esetben tudtunk egyértelmúen állást foglalni a diffúz alveolaris károsodás (DAD) fázisáról, amely 6 esetben exsudativ (2/A ábra), 11 esetben proliferativ (2/E ábra) szakaszba tartozott. Habár eseteink között szerepelt 2, SARS-CoV-2-fertőzés utáni állapot, e betegeknél fibroticus fázisú DAD-ot nem kórisméztünk. Véralvadási rendszerrel kapcsolatos szövődményeket 13 betegnél figyeltünk meg. Infarktussal járó pulmonalis thromboemboliát észleltünk 4 betegnél ( $1 / C$ ábra), ennek forrása 3 esetben alsó végtagi mélyvénás thrombosis, 1 esetben pedig vena brachiocephalica thrombosis volt. Kisebb pulmonalis artériában 5 esetben mutatkozott macrothrombus, és 7 betegnél észleltünk arteriolában vagy capillarisokban microthrombust $(2 / D$ ábra). További thromboticus szövődményként $1-1$ esetben akut coronariathrombosis, valamint aortabillentyün kialakult maranticus endocarditis, illetve jobb kamrai fali thrombus igazolódott. Vérzéses szövődményeket figyeltünk meg 4 betegnél. Az utóbbiak közé a masszív tüdővérzés $(\mathrm{n}=2)$, a retroperitonealis haematoma $(\mathrm{n}=1)$, illetve a kiterjedt mediastinalis haematoma $(\mathrm{n}=1)$ tartozott. SARS-CoV-2-nukleokapszid (B46F)-immunfestéssel 16 eset bizonyult negatívnak, közülük 7 esetben zavaróan erős háttérfestődést észleltünk. Anti-SARSCoV-2-nukleokapszid-expressziót 10 betegnél észleltünk, akik közül 3 esetben diffúz, 7 esetben fokális festődés látszott. Pozitív reakciót észleltünk a hialinmembránban ( $\mathrm{n}=7,2 / \mathrm{F}$ ábra), az intraalveolaris macrophagokban $(\mathrm{n}=5)$, illetve 1 esetben a pneumocytákban. A várakozásokkal ellentétben a vírus cytopathiás hatásokat mutató pneumocyták negatívnak bizonyultak. A tü-
3. táblázat |A tüdőben észlelt további eltérések

\begin{tabular}{|c|c|c|c|}
\hline & & $\begin{array}{c}\text { Jelen } \\
\operatorname{van}(\mathrm{n})\end{array}$ & $\%$ \\
\hline \multicolumn{2}{|c|}{ Centriacinaris emphysema } & 15 & 57,7 \\
\hline \multicolumn{2}{|c|}{ Anthracosis } & 3 & 11,5 \\
\hline \multicolumn{2}{|c|}{ Dohányzással összefüggő interstitialis fibrosis } & 2 & 7,7 \\
\hline \multicolumn{2}{|c|}{ Dendriform pulmonalis ossificatio } & 1 & 3,8 \\
\hline \multicolumn{2}{|c|}{ Szokványos interstitialis pneumonia } & 1 & 3,8 \\
\hline \multicolumn{2}{|c|}{ Metastaticus meszesedés* } & 1 & 3,8 \\
\hline \multicolumn{4}{|c|}{ *Hátterében krónikus veseelégtelenség igazolódott. } \\
\hline \multirow{2}{*}{\multicolumn{2}{|c|}{$\begin{array}{l}\text { további szervkimetszések vizsgálata } \\
\text { os eltérések }\end{array}$}} & án észlel & kroszkó- \\
\hline & & $\begin{array}{c}\text { Jelen } \\
\operatorname{van}(\mathrm{n})\end{array}$ & $\%$ \\
\hline \multicolumn{2}{|c|}{ Hypertensiv vesebetegség } & 12 & 46,2 \\
\hline \multicolumn{2}{|c|}{ Szívizomrost-hypertrophia } & 12 & 46,2 \\
\hline \multicolumn{2}{|c|}{ Steatosis hepatis } & 7 & 26,9 \\
\hline \multicolumn{2}{|c|}{ Centrilobularis haemorrhagiás necrosis } & 3 & 11,5 \\
\hline \multicolumn{2}{|c|}{ Akut tubularis necrosis } & 3 & 11,5 \\
\hline \multicolumn{2}{|l|}{ Splenitis } & 2 & 7,7 \\
\hline \multicolumn{2}{|c|}{ Álhártyás colitis } & 2 & 7,7 \\
\hline \multicolumn{2}{|c|}{ Mellékvesevelő fokális necrosis } & 1 & 3,8 \\
\hline \multicolumn{2}{|l|}{ Erysipelas } & 1 & 3,8 \\
\hline \multicolumn{2}{|c|}{ IgA-nephropathia } & 1 & 3,8 \\
\hline \multicolumn{2}{|c|}{ Maranticus endocarditis } & 1 & 3,8 \\
\hline \multicolumn{2}{|c|}{ Heveny pyelonephritis } & 1 & 3,8 \\
\hline
\end{tabular}

IgA = immunglobulin-A

dőben észlelt további - COVID-19-pneumoniához nem köthető - morfológiai eltérések közül, melyeket a 3. táblázat ismertet, a centriacinaris emphysemát és az anthracosist emeljük ki. A további szervkimetszések vizsgálata során megfigyelt szövettani jellegzetességeket a 4. táblázatban mutatjuk be. Viszonylag magas számban észleltünk hypertensiv vesebetegséget, hypertensiv vagy ischaemiás eredetû szívizom-hypertrophiát, illetve zsírmájat. Egy esetben lymphocytás pharyngitis tûnt szembe, jelentős vírus cytopathiás hatások nélkül. A halottvizsgálati bizonyítványokon feltüntetett - szükség esetén revideált - alapbetegségeket, szövődményeket, halálokokat és társbetegségeket az 1. táblázat részletezi.

A SARS-CoV-2-fertőzés 21 esetben okozott halálos pneumoniát. A leggyakoribb, közvetlen haláloknak a patológuskollégák a légzési elégtelenséget jelölték meg. A SARS-CoV-2-fertőzés mellett felbukkanó leggyakoribb társbetegség a hypertonia essentialis $(\mathrm{n}=17)$ volt, melyet az atherosclerosis és az ischaemiás szívbetegség $(\mathrm{n}=14)$, valamint a 2 -es típusú cukorbetegség $(\mathrm{n}=8)$, a krónikus obstruktív tüdőbetegségek $(\mathrm{n}=4)$ és az elhízás 
követett $(\mathrm{n}=3)$. Vizsgálatunkban 3 vesetranszplantált beteg és 2 , interstitialis tüdőbetegség miatt kezelt páciens volt. A SARS-CoV-2-fertőzés 5 betegnél társbántalomként került megjelölésre. Náluk a halált disszeminálódott carcinoma, elörehaladott akut myeloid leukaemia, hirtelen szívhalál, valamint mentális retardáció következményes elváltozása okozta. Ezen betegek közül 2 esetben látszottak cytopathiás pneumocyták, illetve 2 esetben volt jelen fokális alveolaris károsodás. Az 5 közül 1 esetben észleltünk SARS-CoV-2-nukleokapszid-antitestexpressziót a pneumocytákban és a macrophagokban. Tumoros betegség egyébként 7 betegnél igazolódott, összegezve: krónikus lymphocytás leukaemia $(\mathrm{n}=2)$, akut myeloid leukaemia, tüdő kissejtes carcinoma, coecum-adenocarcinoma, tüdő-laphámcarcinoma, valamint hypophysisadenoma. A kórboncolás a betegek mintegy háromnegyedénél mutatott ki új észleletet, melyek csökkenő gyakoriságban a következők voltak: tumorverifikáció $(\mathrm{n}=7)$, COVID-19-pneumonia $(\mathrm{n}=4)$ és/vagy bronchopneumonia $(\mathrm{n}=4)$ igazolása, tumoros betegség kizárása $(\mathrm{n}=3)$, dilatativ cardiomyopathia $(\mathrm{n}=1)$ és maranticus endocarditis $(\mathrm{n}=\mathrm{l})$.

\section{Megbeszélés}

A halálos COVID-19-tüdőbetegségben elhunytak boncolására a pandémia kezdetén szerte a világon csak igen ritkán került sor, ilyenkor szövettanilag az elhunytak egy részénél DAD-ot észleltek: a pneumocyták a lumenbe lökődtek, a szaporodó vírus cytopathiás eltéréseket idézett elő, az alveolusok lumenében vizenyő és hialinmembránok jelentek meg, az alveolaris septumok vizenyősen kiszélesedetté váltak, a septalis elasztikus rostok pedig kiterjedten pusztultak. A veleszületett immunválasz túlaktiválódása az alveolusok lumenében és a septumokban monocyta/macrophag és neutrophil granulocyta szaporulatot, az interalveolaris capillarisokban microthrombosist idézett elő. A szövettani képet számos tényező befolyásolta, mint például a tünetek kezdetétől eltelt idő, a gépi lélegeztetés okozta barotrauma, a rárakódott nosocomialis fertőzés stb. Boncolási anyagunkban halálos COVID-19-pneumoniát túlnyomóan az idős, polimorbid (hypertoniás, atheroscleroticus, diabeteses stb.) férfiakban észleltünk. Az észlelet magyarázata nem egyszerú. Az időskor gyengébb immunválaszra, ugyanakkor a proinflammatoricus citokinek intenzívebb termelésére hajlamosít. A férfiak nőktől eltérő hormonszintjei kedvezőtlenül befolyásolhatják a gyulladásos folyamatok szabályozását; életmódi tényezők - például az angiotenzinkonvertáló enzim-2 receptorának dohányzás kiváltotta dúsulása a bronchiolusokban - fokozhatják a tüdő vírusterhelését; a hypertonia és a diabetes megváltoztathatja a renin-angiotenzin-aldoszteron ösvények egyensúlyát [3].

Morfológiailag a tüdő elváltozásaira jellemző a multifokalitás: normális tüdőparenchyma váltakozik gyulladt régiókkal [16]. Mint az 1. ábrán bemutattuk, makro- szkóposan a COVID-19-pneumoniás tüdők nehezek, tömöttek; a konszolidáció jeleként vizenyő és kétoldali, multifokális vérbőség/vérzések figyelhetők meg, melyeket az arteria pulmonalis ágak thrombusai/embolusai kiváltotta elváltozások - bevérzés, vérzéses elhalás - színeznek [17-19]. Szövettanilag a betegség kezdetétől eltelt idő függvényében kétoldali, multifokális megjelenésû eDAD látható prominens hialinmembrán-képződéssel (2/A ábra), vagy proliferativ szakaszba lépett DAD (2/E ábra) észlelhető interstitium-kiszélesedést okozó friss kollagénfelhalmozódással, intraalveolaris Masson-polyp-képződéssel és/vagy laphám-metaplasiával [18-20]. Chmielik és mtsai közleményükben az esetek egy részében DAD helyett interstitialis lymphoid infiltratiót (2/Cábra) és vírus cytopathiás jellegzetességeket mutató, II-es típusú pneumocytákat emelnek ki [21]. Az utóbbaikra jellemző a sejtmagméret megnagyobbodása (2/B ábra-inszert), a prominens, szabálytalan nucleolus és a többmagvúság [19]. Emellett további kutatók a COVID-19 specifikus sajátságaként a thromboticus microangiopathiára hívják fel a figyelmet $[22,23]$. Általában a szervülés különböző fázisaiban levő microthrombusok mind a prae-, mind a postcapillaris erekben jelen lehetnek [18].

A COVID-19 által okozott extrapulmonalis szervi eltérések közül általában a szív, a vese, a máj, az agy, a lép és a csontveló laesióit emelik ki [5]. A SARS-CoV-2-vel asszociált szív makroszkópos morfológiai eltérések között említik a balkamra-hypertrophiát [24]. A szövettani észleletek igen változatosak: észleltek normális szerkezetû myocardiumot, lymphocytás myocarditist, izolált myocytanecrosist, ischaemiás szívbetegséget [25], interstitialis vizenyőt, microvérzéseket [26], illetve macrophagakkumulációt [20]. Az irodalom szerint ezek az eltérések azonban nem specifikusak SARS-CoV-2-fertőzésre, sốt a betegek igen gyakran cardialis eredetû társbetegségekben szenvednek. A szívbeli szöveti eltérések értékelésekor ezeket a tényezőket mindig figyelembe kell venni [5]. Saját észleleteink közül a hypertensiv, az ischaemiás eredetú szívbetegségeket, illetve l-1 esetben a maranticus endocarditist és a dilatativ cardiomyopathiát emelnénk ki. Menter és mtsai a vesében leggyakrabban előforduló makroszkópos eltérésként a sokkvese képét észlelték [24]. Mikroszkóposan dominálóan a proximalis kanyarulatos csatornát érintő akut tubularis necrosis látható, de gyakoriak a veseerekben észlelhetó thrombusok és fokális bevérzések [27]. Természetesen a vesében is igaz, hogy a korábban már kialakult, így például hypertensiv vagy diabeteses vesekárosodást el kell különíteni a COVID-19 renalis következményeitól. Menter és kutatótársai eredményeivel összhangban 3 esetben akut tubularis necrosist figyeltünk meg [24]. Gauchotte és mtsai a máj vizsgálata során COVID-19 esetén a leggyakrabban centrilobularis haemorrhagiás necrosist és enyhe lebenyi vagy portalis gyulladást [28], illetve az intrahepaticus erekben thrombosist észleltek. Saját tapasztalataink szerint a májban a nem specifikus steatosis, illetve a cent- 
rilobularis haemorrhagiás necrosis fordult elő. Ugyanakkor a máj szövettani értékelésekor is figyelembe kell venni a betegség előtt már meglevő májkárosodást, mint például a diabeteshez, elhízáshoz társult steatosist. A SARS-CoV-2-fertőzés által okozott agyi eltéréseket illetően megoszlanak a vélemények. Egyes szerzők enyhe, fokális agytörzsi gyulladást észleltek a károsodott, néha microthrombusokat is tartalmazó erek körül, illetve vizenyő mellett elszórtan bevérzett területeket figyeltek meg [29], míg mások nem láttak eltéréseket az agyban az esetleges hypoxia következményein kívül [30]. Saját anyagunkban a 3 boncolt agy esetében az agytörzsben és a hypothalamusban igen kifejezett microglia-aktiváció igazolódott. Sessa és mtsai összefoglaló közleményükben a léppel kapcsolatban a fehér pulpa atrophiáját, valamint a vörös pulpa túltengését, továbbá thrombusok, infarktusok, illetve vérzések jelenlétét említik. A csontvelőben előfordulhat haemophagocytosis. A SARS-CoV-2-fertőzésre két mintázat jellemző. Az egyikben a sárga csontvelő (zsírszövet) túlsúlyba kerülése látszik, míg a másikat a vörös csontvelő hyperplasiája jellemzi [5]. Szövettani vizsgálataink során a lépet illetôen 2 esetben észleltük a fehér pulpa deplécióját, illetve 1 esetben figyeltük meg a csontvelő hipocellularitását, zsíros involúcióját.

A COVID-19 mellett előforduló társbetegségek zöme megegyezett a szakirodalomban leírtakkal [24]. Kiemeljük, hogy vizsgálatunkban halálos SARS-CoV-2-fertőzés időskor és/vagy társult betegség(ek) nélkül nem fordult elő. Az idős korosztályból az egyetlen kivételt egy 2 éves, mentális retardációval kórismézett gyermek jelentette, aki szociális intézményben kapta el a fertőzést. Nála a kórházi kezelés során a SARS-CoV-2-PCR-teszt már negatív volt, de vena brachiocephalica thrombosis, majd pulmonalis embolia alakult ki következményes tüdőelhalással. Saját anyagunkban némileg alacsonyabb arányban volt jelen a hypertonia essentialis $(65,3 \%$ vs. $100 \%)$, a cardiovascularis betegség ( $53,8 \%$ vs. $71 \%$ ), az elhízás (11,5\% vs. $29 \%$ ), valamint a krónikus neurológiai eltérések (15,4\% vs. $24 \%$ ), viszont betegeink körében gyakoribb volt a daganatok előfordulása $(26,9 \%$ vs. $15 \%)$ és a szerzett immunhiányos állapot $(11,5 \%$ vs. $5 \%)$. A leírt különbségek hátterében állhatnak genetikai tényezők, továbbá az a tény is, hogy Menter és mtsai vizsgálatában a betegek átlagéletkora mintegy 10 évvel magasabb volt a saját kutatásunkba bevont betegekhez képest [24].

Mivel a patológusok számára kézenfekvő megoldás lehetne a vírus immunhisztokémiai kimutatása, erre a kérdésre egyre több tanulmány fókuszál. A kereskedelmi forgalomban számos antitest áll rendelkezésre, amelyek a leggyakrabban a nukleokapszid vagy a „spike” (tüske) protein egyes epitopjai ellen termeltettek. Saját eredményeink szerint az általunk használt SARS-CoV-2-nukleokapszid (B46F)-antitest pozitivitása 38,5\% volt (95\% CI: 0,24-0,61). A rendelkezésre álló irodalmi adatok szerint a különböző antitestek szenzitivitása igen változó, mintegy 71-92\% közötti [31-33], de a saját adatainknál jóval magasabb. A markerek specificitása további vizsgálatokat igényel, mivel a különböző közlemények más-más markereket tartanak SARS-CoV-2-specifikusnak [34, 35]. Az irodalmi adatokkal összhangban saját eredményeink is alátámasztják, hogy a pozitív immunhisztokémiai reakció elsősorban a betegség korai szakaszában fordul elő, amikor a leggyakrabban eDAD észlelhető a tüdőben. A COVID-19 korai szakaszában jelen levő expressziót támogatja, hogy a SARS-CoV-2-nukleokapszid-pozitív eseteinknél a betegség időtartamának átlaga 9 nap (medián: 4 nap) volt, míg az expressziót nem mutató esetekben a betegség hosszának átlaga 13 napnak (medián: 14 nap) bizonyult. A szakirodalmi adatokkal összhangban az immunhisztokémiai reakció a tüdőben a hialinmembránban, a macrophagokban és a pneumocytákban észlelhető. Sauter és mtsai endothelsejtekben és bronchushámban is észleltek pozitivitást, ez nálunk nem fordult elő [31]. Massoth és mtsai az in situ hibridizációs, az immunhisztokémiai és a PCR-alapú SARS-CoV-2-detektálás szenzitivitását és specificitását vizsgálták tüdőben és extrapulmonalis szervekben [36]. Az utóbbiakban konzekvensen nem tudták kimutatni a vírus jelenlétét, ezért döntöttünk csak a tüdőszövet vizsgálata mellett.

Az immunhisztokémiai markerek expresszióját számos tényező befolyásolja, így a mono- vagy poliklonalitás, az antigén jellege, a DAD fázisa, illetve a betegség időtartama. Saját tapasztalataink alapján az általunk vizsgált antitest esetében a reakció nemritkán nehezen olvasható az erős háttérfestődés miatt, illetve a fibrinből és sejttörmelékből álló hialinmembrán, továbbá a macrophagok pozitivitása a specifikusság szempontjából kérdéseket vet fel. A közlemények általában nem közlik a halál és a boncolás között eltelt időt sem, amely szintén befolyásolhatja a kórokozó immunhisztokémiai kimutathatóságát. Az optimális specificitású és szenzitivitású immunhisztokémiai markerek kiválasztásához további, a jelenlegi közleményeknél nagyobb elemszámú vizsgálatokra van szükség. Amíg ezen vizsgálatok eredményei nem állnak rendelkezésre, a vírusfertőzést - paraffinos blokkból is post mortem PCR-reakcióval lehet igazolni, amennyiben a patológusokban a SARS-CoV-2-fertőzés mint etiológiai tényező felmerül. Vizsgálatunk korlátai közé tartozik többek között a kutatás retrospektív jellege, a több esetben hiányos klinikai adatok, valamint a kórboncolás és a szervkimetszések standardizáltságának hiánya. További nehézség a halottvizsgálati bizonyítvány korrekt kitöltése SARS-CoV-2-fertőzés esetén, mivel sok betegnél az eset komplexitása még a tapasztaltabb kollegáknál is megnehezíti az alapbetegség és a társbetegségek egyértelmü identifikálását.

\section{Következtetés}

Munkánkban két hazai intézményben elhunyt betegek boncolása során nyert tapasztalatok bemutatásával hívjuk fel a figyelmet a SARS-CoV-2-fertőzés post mortem gyanújeleire, melyek alapján indikált a SARS-CoV-2- 
PCR-vizsgálat. A post mortem PCR-mintavétel az alsó légutakból, az alveolaris régióból is lehetséges, ami in vivo nem kivitelezhető. Saját tapasztalataink alapján az alsó légúti mintából a vírusfertőzés kimutatása akár a halál után 7 nappal, de Edler és mtsai eredményei szerint még 12 nappal később is sikeres [37]. A vírus immunhisztokémiai alapú detektálása leginkább a DAD korai fázisában lehetséges.

Anyagi támogatás: A közlemény megírása, illetve a kapcsolódó kutatómunka anyagi támogatást nem kapott.

Szerzôi munkamegosztás: Z. T.: A koncepció és a metodika kidolgozása, adatgyưjtés, adatelemzés, a kézirat megszövegezése, végleges formába öntése, jóváhagyása. Ku. L., H. T., Cs. E., Á. J., Ko. L., S. I., Ka. L., R. B., P. T., Ny. G. R., B. B., S. A.: Adatgyưjtés, a kézirat megszövegezése, végleges formába öntése, jóváhagyása. Cs. G.: A koncepció kidolgozása, adatgyűjtés, a kézirat megszövegezése, végleges formába öntése, jóváhagyása. I. B.: A koncepció kidolgozása, adatelemzés; a kézirat megszövegezése, végleges formába öntése, jóváhagyása. T. L.: A koncepció kidolgozása, a kézirat megszövegezése, végleges formába öntése, jóváhagyása.

Érdekeltségek: A szerzőknek nincsenek érdekeltségeik.

\section{Köszönetnyilvánítás}

Köszönetünket fejezzük ki Dezső Mihálynak (SZTE, Patológiai Intézet), dr. Zombori Jánosnak (Csongrád-Csanád Megyei Egészségügyi Ellátó Központ, Hódmezővásárhely) és dr. Hamar Sándornak (SZTE, Patológiai Intézet) a fotódokumentáció összeállításában nyújtott segítségükért.

\section{Irodalom}

[1] Corman VM, Lienau J, Witzenrath M. Coronaviruses as a cause of respiratory infections. [Coronaviren als Ursache respiratorischer Infektionen.] Internist 2019; 60: 1136-1145. [German]

[2] Zhou P, Yang XL, Wang XG, et al. A pneumonia outbreak associated with a new coronavirus of probable bat origin. Nature 2020; 579: 270-273.

[3] Gao YD, Ding M, Dong X, et al. Risk factors for severe and critically ill COVID-19 patients: a review. Allergy 2021; 76: 428-455.

[4] Lowery SA, Sariol A, Perlman S. Innate immune and inflammatory responses to SARS-CoV-2: implications for COVID-19. Cell Host Microbe 2021; 29: 1052-1062.

[5] Sessa F, Salerno M, Pomara C. Autopsy tool in unknown diseases: The experience with coronaviruses (SARS-CoV, MERSCoV, SARS-CoV-2). Medicina 2021; 57: 309.

[6] Salerno M, Sessa F, Piscopo A, et al. No autopsies on COVID-19 deaths: a missed opportunity and the lockdown of science. J Clin Med. 2020; 9: 1472 .

[7] National Center of Public Health. Directions related to deceased. Budapest, 23th March 2020. [Halottakkal kapcsolatos rendelkezések.] Nemzeti Népegészségügyi Központ, Budapest, 2020. március 23. Available from: http://pathology.hu/hu/ hirek/1574/emmi-es-nnkutasitasai-halottvizsgalattal-kapcsolat ban [accessed: June 12, 2021]. [Hungarian]

[8] Ministry of Human Capacities. Arrangements related to autopsies during State of Emergency. Budapest, 23th March 2020 [Kórboncolással kapcsolatos intézkedések veszélyhelyzet idején.] Emberi Erőforrások Minisztériuma, Budapest, 2020. március 23. Available from: http://pathology.hu/hu/hirek/1578/boncolasok-felfuggesztese-miniszterikiegeszites [accessed: June 12, 2021]. [Hungarian]

[9] Centers for Disease Control and Precention. Severe acute respiratory syndrome (SARS). Available from: https://www.cdc gov/sars/index.html [accessed: June 11, 2021].

[10] Hanley B, Lucas SB, Youd E, et al. Autopsy in suspected COVID-19 cases. J Clin Pathol. 2020; 73: 239-242.

[11] World Health Organization. Infection prevention and control for the safe management of a dead body in the context of COVID-19: interim guidance. WHO, Geneva. Available from: https://www. who.int/publications/i/item/infection-prevention-and-control-for-the-safe-management-of-a-dead-body-in-the-contextof-covid-19-interim-guidance [accessed: June 11, 2021].

[12] Farkas CsB, Petrétei D, Babinszky G, et al. Role of duties related to COVID-19 suspected, probable and confirmed fatality cases. [Elhunytakkal kapcsolatos teendők COVID-19-gyanús, valószínúsített és megerősített esetekben.] Orv Hetil. 2020; 161: 713722. [Hungarian]

[13] Ministry of Human Capacities. Ministerial instruction on the death examination - Budapest, 21 th March 2020. [Miniszteri utasítás a halottvizsgálattal kapcsolatban.] Emberi Erőforrások Minisztériuma, Budapest, 2020. március 21. Available from: https://pathology.hu/uploads/files/EMMI\%20utasitas\%20 halottvizsgalattal\%20kapcsolatban.pdf [accessed: July 7, 2021]. [Hungarian]

[14] Calabrese F, Pezzuto F, Fortarezza F, et al. Pulmonary pathology and COVID-19: lessons from autopsy. The experience of European pulmonary pathologists. Virchows Arch. 2020; 477: 359-372.

[15] Best Rocha A, Stroberg E, Barton LM, et al. Detection of SARSCoV-2 in formalin-fixed paraffin-embedded tissue sections using commercially available reagents. Lab Invest. 2020 ; 100: 14851489.

[16] Youd E, Moore L. COVID-19 autopsy in people who died in community settings: the first series. J Clin Pathol. 2020; 73 : 840-844

[17] Rapkiewicz AV, Mai X, Carsons SE, et al. Megakaryocytes and platelet-fibrin thrombi characterize multi-organ thrombosis at autopsy in COVID-19: a case series. E Clinical Medicine 2020; 24: 100434 .

[18] Grosse C, Grosse A, Salzer HJ, et al. Analysis of cardiopulmonary findings in COVID-19 fatalities: high incidence of pulmonary artery thrombi and acute suppurative bronchopneumonia. Cardiovasc Pathol. 2020; 49: 107263.

[19] Bradley BT, Maioli H, Johnston R, et al. Histopathology and ultrastructural findings of fatal COVID-19 infections in Washington State: a case series. Lancet 2020; 396: 320-332.

[20] Li Y, Wu J, Wang S, et al. Progression to fibrosing diffuse alveolar damage in a series of 30 minimally invasive autopsies with COVID-19 pneumonia in Wuhan, China. Histopathology 2021; 78: 542-555.

[21] Chmielik E, Jazowiecka-Rakus J, Dyduch G, et al. COVID-19 autopsies: a case series from Poland. Pathobiology 2021; 88: 78-87.

[22] Lax SF, Skok K, Zechner P, et al. Pulmonary arterial thrombosis in COVID-19 with fatal outcome: results from a prospective, single-center, clinicopathologic case series. Ann Intern Med. 2020; 173: 350-361

[23] Remmelink M, De Mendonça R, D’Haene N, et al. Unspecific post-mortem findings despite multiorgan viral spread in COVID-19 patients. Crit Care 2020; 24: 495. 
[24] Menter T, Haslbauer JD, Nienhold R, et al. Post-mortem examination of COVID-19 patients reveals diffuse alveolar damage with severe capillary congestion and variegated findings of lungs and other organs suggesting vascular dysfunction. Histopathology 2020; 77: 198-209.

[25] Dolhnikoff M, Duarte-Neto AN, de Almeida Monteiro RA, et al. Pathological evidence of pulmonary thrombotic phenomena in severe COVID-19. J Thromb Haemost. 2020; 18: 1517-1519.

[26] Basso C, Leone O, Rizzo S, et al. Pathological features of COVID-19-associated myocardial injury: a multicentre cardiovascular pathology study. Eur Heart J. 2020; 41: 3827- 3835.

[27] Cîrstea A-E, Buzulică RL, Pirici D, et al. Histopathological findings in the advanced natural evolution of the SARS-CoV-2 infection. Rom J Morphol Embryol. 2020; 61: 209- 218.

[28] Gauchotte G, Venard V, Segondy M, et al. SARS-Cov-2 fulminant myocarditis: an autopsy and histopathological case study. Int J Leg Med. 2021; 135: 577-581.

[29] Nuovo GJ, Magro C, Shaffer T, et al. Endothelial cell damage is the central part of COVID-19 and a mouse model induced by injection of the S1 subunit of the spike protein. Ann Diagn Pathol. 2021; 51: 151682 .

[30] Solomon IH, Normandin E, Bhattacharyya S, et al. Neuropathological features of Covid-19. N Engl J Med. 2020; 383: 989992.

[31] Sauter JL, Baine MK, Butnor KJ, et al. Insights into pathogenesis of fatal COVID-19 pneumonia from histopathology with im- munohistochemical and viral RNA studies. Histopathology 2020; 77: 915-925.

[32] Schaefer IM, Padera RF, Solomon IH, et al. In situ detection of SARS-CoV-2 in lungs and airways of patients with COVID-19. Mod Pathol. 2020; 33: 2104-2114.

[33] Martines RB, Ritter JM, Matkovic E, et al. Pathology and pathogenesis of SARS-CoV-2 associated with fatal coronavirus disease, United States. Emerg Infect Dis. 2020; 26: 2005-2015.

[34] Szabolcs M, Sauter JL, Frosina D, et al. Identification of immunohistochemical reagents for in situ protein expression analysis of coronavirus-associated changes in human tissues. Appl Immunohistochem Mol Morphol. 2021; 29: 5-12.

[35] Liu J, Babka AM, Kearney BJ, et al. Molecular detection of SARS-CoV-2 in formalin-fixed, paraffin-embedded specimens. JCI Insight 2020; 5: el39042.

[36] Massoth LR, Desai N, Szabolcs A, et al. Comparison of RNA in situ hybridization and immunohistochemistry techniques for the detection and localization of SARS-CoV-2 in human tissues. Am J Surg Pathol. 2021; 45: 14-24.

[37] Edler C, Schröder AS, Aepfelbacher M, et al. Dying with SARS$\mathrm{CoV}-2$ infection - an autopsy study of the first consecutive 80 cases in Hamburg, Germany. Int J Legal Med. 2020; 134: 12751284.

(Zombori Tamás dr., Szeged, Állomás u. 1., 6725 e-mail: zomtam@gmail.com)

\section{"Hic mortui vivos docent." (Itt a holtak tanítják az élőket.)}

A cikk a Creative Commons Attribution 4.0 International License (https://creativecommons.org/licenses/by/4.0/) feltételei szerint publikált Open Access közlemény, melynek szellemében a cikk bármilyen médiumban szabadon felhasználható, megosztható és újraközölhető, feltéve, hogy az eredeti szerző és a közlés helye, illetve a CC License linkje és az esetlegesen végrehajtott módosítások feltüntetésre kerülnek. (SID_1) 